\title{
Comparison of iron carboxy maltose and iron sucrose in pregnant females
}

\author{
Isha Sunil $^{1}$, Prabhjit Kour ${ }^{1}$, Mitali Sharma ${ }^{2 *}$
}

\begin{abstract}
${ }^{1}$ Department of Obstetrics and Gynecology, ${ }^{2}$ Department of Transfusion Medicine, ASCOMS, Jammu, Jammu and Kashmir, India
\end{abstract}

Received: 03 December 2018

Accepted: 07 January 2019

\author{
*Correspondence: \\ Dr. Mitali Sharma, \\ E-mail: mitali89sharma@gmail.com
}

Copyright: (c) the author(s), publisher and licensee Medip Academy. This is an open-access article distributed under the terms of the Creative Commons Attribution Non-Commercial License, which permits unrestricted non-commercial use, distribution, and reproduction in any medium, provided the original work is properly cited.

\begin{abstract}
Background: Maternal anaemia is a common problem worldwide. The aim of this study is to compare the efficacy and safety of FCM vs iron sucrose for correction of iron deficiency during pregnancy.

Methods: This study was conducted in Swasthya healthcare, Jammu for a period of ten months from Sep 2017 to June 2018. A total of 100 women with $\mathrm{Hb} 7-9.9 \mathrm{~g} \%$ enrolled. They were divided into two groups of 50 each. Group A were given Iron Carboxy maltose and Group B were given Iron Sucrose. These were compared for their efficacy and safety.

Results: In the present study, the rise in mean hemoglobin at 4 weeks in Group A was $1.79 \pm 0.47$ and $1.06 \pm 0.11$ in Group B which was highly significant (p-value $<0.0001$ ). Rise in mean serum ferritin level at 4 weeks in Group A was $123.80 \pm 16.03$ and in Group B was $84.78 \pm 10.53$. Statistically, this rise was also highly significant $(\mathrm{p}<0.0001)$. In present study, adverse reactions were observed in $34 \%$ patients in Group A, while in Group B it was observed in 52\% patients.

Conclusions: Iron carboxy maltose shows higher rise in hemoglobin and ferritin levels as compared to Iron Sucrose and incidence of adverse effects is also comparatively lower in the former.
\end{abstract}

Keywords: Anaemia, Iron carboxy maltose, Iron sucrose

\section{INTRODUCTION}

Maternal anaemia is a common problem especially in developing countries like India. One of the studies conducted revealed that $87 \%$ of the women in India are anaemic. ${ }^{1}$ According to the 2008 WHO analysis, anaemia affected $24.8 \%$ of the world's population.

Anaemia in pregnancy is defined as haemoglobin concentration $<11 \mathrm{gm} \%$ and further categorised into three levels: mild: $9-10.9 \mathrm{gm} / \mathrm{dl}$, moderate:7-8.9gm/dl; severe: $<7 \mathrm{gm} / \mathrm{dl} .^{2}$ Maternal anaemia in pregnancy is commonly considered as risk factor for poor pregnancy outcomes like pre-eclampsia, antepartum haemorrhage, preterm deliveries and maternal mortality. ${ }^{3}$ Maternal anaemia is also associated with poor perinatal outcome like low birth weight babies, meconium stained liquor, low APGAR scores at one min and NICU admissions. ${ }^{4}$ Among the pregnant women the most common type of anaemia is iron deficiency anaemia as shown by several studies. ${ }^{5}$

The mainstay of treatment for iron deficiency anaemia is iron supplementation either oral or parental. The indications for parental iron treatment are intolerance to oral iron, non-compliance to oral iron and patients who need rapid restoration of iron stores. Current intravenous iron formulations include ferric gluconate, iron sucrose, iron polymaltose and, recently, ferric carboxymaltose. ${ }^{5}$ They have the same structure, but differ from each other by the size of the core and the surrounding carbohydrate. 
Iron sucrose and ferric carboxy maltose (FCM) are dextran free intravenous iron alternatives. Iron sucrose has widely been used as it has a higher availability for erythropoiesis than iron dextran a good safety profile in pregnancy. ${ }^{6}$ However, it cannot be administered in a higher dose and re-quires frequent visits to the hospital by a pregnant woman. Intravenous ferric carboxy maltose is a novel iron complex which consists of a ferric hydroxide core which is stabilised by a carbohydrate shell. It is not predisposed to anaphylactic reactions since it has a low immunogenic potential. Upon administration, it allows controlled delivery of iron within the cells of the reticuloendothelial system which further deliver to the iron-binding proteins ferritin and transferrin. Studies have shown that it is rapidly cleared from the circulation and is distributed primarily to the bone marrow and also to the liver and spleen and there is no risk of accumulation of iron in patients with iron-deficiency anaemia. ${ }^{7}$ Ferric carboxy maltose also per-mits the administration of large doses (15 mg/kg; maximum of $1000 \mathrm{mg} / \mathrm{infusion})$ in a single and rapid session (15-minute infusion). The aim of this study is to compare the efficacy and safety of FCM vs iron sucrose during pregnancy for correction of iron deficiency during pregnancy.

\section{METHODS}

This was a prospective, comparative study conducted in Swasthya healthcare, Jammu from $1^{\text {st }}$ September 2017 to $30^{\text {th }}$ June 2018 over a period of 10 months.

\section{Inclusion criteria}

- Hundred antenatal patients with gestational age more than 28 weeks and moderate anaemia with hemoglobin 7-9.9gm and S. Ferritin levels <30mcg were included in the study.

\section{Exclusion criteria}

- Patients with history of blood transfusion, hypersensitivity reaction to any iron preparation, history of bleeding tendencies, history of iron overload disorders, thalassemia's or haemochromatosis or medical disorders like chronic renal failure, cardiovascular disorder, tuberculosis, hepatitis $\mathrm{B} / \mathrm{C}$ or HIV infection were excluded from the study.

These patients were evaluated for $\mathrm{CBC}, \mathrm{PBF}$ and $\mathrm{S}$. Ferritin levels. These patients were divided into a group of 50 each: Group A and Group B. Group A were given ferric carboxy maltose and Group B subjects were given iron sucrose.

The dose of intravenous iron was calculated by the following formula:

Total iron requirement $=2.4 \mathrm{x}$ body weight (in $\mathrm{kgs}$ ) $\mathrm{x}$ hemoglobin deficit+500mg (iron stores).
Hemoglobin deficit was calculated by subtracting from $11 \mathrm{gm} \%$.

FCM was administered by intravenous drip infusion. The iron requirement dose was rounded down to nearest 100 $\mathrm{mg}$ if body weight $<66 \mathrm{~kg}$ and rounded up to nearest 100 $\mathrm{mg}$ if body weight $>66 \mathrm{~kg}$. FCM was diluted to a maximum single dose of $1000 \mathrm{mg}$ iron in $250 \mathrm{ml}$ normal saline and given over a period of 15 minutes. Iron sucrose was given as an infusion of $200 \mathrm{mg}$ in $200 \mathrm{ml}$ of normal saline over 15 minutes on al-ternate days till the required dose was met. After the iron infusion the patients were observed for adverse reactions like itching, headache, nausea, fever, pain at injection site or severe anaphylactic reaction. Complete blood count and S. Ferritin levels were repeated 2 weeks after the last dose of FCM or iron sucrose.

\section{RESULTS}

The data was analysed, and following observations made.

Table 1: Distribution of patients according to age.

\begin{tabular}{|l|l|l|}
\hline Age (years) & $\begin{array}{l}\text { Group A } \\
\text { No. (\%) }\end{array}$ & $\begin{array}{l}\text { Group B } \\
\text { No. (\%) }\end{array}$ \\
\hline $15-19$ & $01(02)$ & $0(0)$ \\
\hline $20-24$ & $23(46)$ & $17(34)$ \\
\hline $25-29$ & $22(44)$ & $22(44)$ \\
\hline $30-34$ & $03(06)$ & $11(22)$ \\
\hline $35-39$ & $01(02)$ & $0(0)$ \\
\hline Total & $50(100.00)$ & $50(100.00)$ \\
\hline Mean \pm SD (years) & $26.46 \pm 3.58$ & $24.64 \pm 2.87$ \\
\hline Statistical inference & $\begin{array}{l}\text { Unpaired t value=2.80; }=0.006 ; \\
\text { Not significant }\end{array}$ \\
\hline
\end{tabular}

As shown in Table 1, mean age of Group A was $26.46 \pm 3.58$ years and mean age of Group B was $24.64 \pm 2.87$ years, which was comparable $(\mathrm{p}=0.006) .44 \%$ of patients in Group A and 38\% in Group B were primigravidae, while $56 \%$ of patients in Group A and $62 \%$ in Group B were multigravida; both groups being statistically comparable $(\mathrm{p}=0.54)$ (Table 2$)$.

Table 2: Gravidity of patients.

\begin{tabular}{|l|l|l|l|}
\hline Gravidity & $\begin{array}{l}\text { Group A } \\
\text { No. }(\%)\end{array}$ & $\begin{array}{l}\text { Group B } \\
\text { No. }(\%)\end{array}$ & $\begin{array}{l}\text { Statistical } \\
\text { inference }\end{array}$ \\
\hline Primigravida & $22(44)$ & $19(38)$ & $\begin{array}{l}\text { Chi square } \\
=0.37\end{array}$ \\
\hline Multigravida & $28(56)$ & $31(62)$ & $\begin{array}{l}\text { p=0.54; Not } \\
\text { significant }\end{array}$ \\
\hline Total & $50(100.00)$ & $50(100.00)$ & \begin{tabular}{l}
50.0 \\
\hline
\end{tabular}
\end{tabular}

Table 3 shows the pre-treatment haemoglobin in the two groups. Patients with haemoglobin level of moderate range $(7-9.9 \mathrm{gm} / \mathrm{dl})$ were included in the study.

Most patients in Group A (46\%) and in Group B (46\%) had their haemoglobin in the range of 8 to $8.9 \mathrm{gm} / \mathrm{dl}$. 
Mean values of haemoglobin in both the groups were comparable statistically $(\mathrm{p}=0.69)$.

Table 3: Pre-treatment haemoglobin (gm/dl) of the patients.

\begin{tabular}{|l|l|l|}
\hline Pretreatment Hb & $\begin{array}{l}\text { Group A } \\
\text { No. }(\%)\end{array}$ & $\begin{array}{l}\text { Group B } \\
\text { No. }(\%)\end{array}$ \\
\hline $7-7.9$ & $14(28.00)$ & $10(20.00)$ \\
\hline $8-8.9$ & $23(46.00)$ & $23(46.00)$ \\
\hline $9-9.9$ & $13(26.00)$ & $17(34.00)$ \\
\hline Total & $50(100.00)$ & $50(100.00)$ \\
\hline Mean $\mathrm{Hb}(\mathrm{g} / \mathrm{dl})$ & $8.45 \pm 0.64$ & $8.40 \pm 0.64$ \\
\hline Statistical inference & $\begin{array}{l}\text { Unpaired t test value }=0.39 ; \\
\mathrm{p}=0.69 ; \text { Not significant }\end{array}$ \\
\hline
\end{tabular}

Patients with serum ferritin less than $30 \mathrm{mcg} / \mathrm{L}$ were included in the study. Mean serum ferritin of Group A was $14.09 \pm 6.05 \mathrm{mcg} / \mathrm{L}$ and that of Group B was $14.74 \pm 5.82 \mathrm{mcg} / \mathrm{L}$, the difference being statistically not significant $(\mathrm{p}=0.58)$ (Table 4$)$.

As shown in Table 5, the rise in mean haemoglobin level at 4 weeks was also more in Group A as compared to Group B (1.79 vs $1.06 \mathrm{gm} / \mathrm{dl})$.
Table 4: Pre-treatment serum ferritin $(\mathrm{mcg} / \mathrm{L})$ of the patients.

\begin{tabular}{|l|l|l|}
\hline $\begin{array}{l}\text { Serum ferritin } \\
(\mathrm{mcg} / \mathrm{L})\end{array}$ & $\begin{array}{l}\text { Group A } \\
\text { No. }(\%)\end{array}$ & $\begin{array}{l}\text { Group B } \\
\text { No. }(\%)\end{array}$ \\
\hline $0-9.9$ & $14(28.00)$ & $14(28.00)$ \\
\hline $10-19.9$ & $25(50.00)$ & $25(50.00)$ \\
\hline $20-29.9$ & $11(22.00)$ & $11(22.00)$ \\
\hline Total & $50(100.00)$ & $50(100.00)$ \\
\hline Mean \pm SD & $14.09 \pm 6.05$ & $14.74 \pm 5.82$ \\
\hline Statistical inference & $\begin{array}{l}\text { Unpaired t test value } \mathrm{t}=0.54 ; \\
\mathrm{p}=0.58 ; \text { not significant }\end{array}$ \\
\hline
\end{tabular}

Statistically, the rise was highly significant $(\mathrm{p}<0.0001)$.

Table 5: Rise in mean haemoglobin (gm/dl) level at 4 weeks.

\begin{tabular}{|l|l|l|l|}
\hline Variable & $\begin{array}{l}\text { Group A } \\
\text { Mean } \pm \text { SD }\end{array}$ & $\begin{array}{l}\text { Group B } \\
\text { Mean } \pm \text { SD }\end{array}$ & $\begin{array}{l}\text { Statistical } \\
\text { inference } \\
\text { (unpaired t test) }\end{array}$ \\
\hline $\begin{array}{l}\text { Rise at } 4 \\
\text { weeks }\end{array}$ & $1.79 \pm 0.47$ & $1.06 \pm 0.11$ & $\begin{array}{l}\mathrm{t}=10.97 ; \\
\mathrm{p}<0.0001 ; \text { highly } \\
\text { significant }\end{array}$ \\
\hline
\end{tabular}

Table 6: Post-treatment rise in serum ferritin (mcg/L) at 4 weeks.

\begin{tabular}{|c|c|c|c|}
\hline \multirow{2}{*}{$\begin{array}{l}\text { Mean rise in S. ferritin } \\
(\mathrm{mcg} / \mathrm{L}) \text { at } 4 \text { weeks }\end{array}$} & Group A & Group B & Statistical interference \\
\hline & $123.80 \pm 16.03$ & $84.78 \pm 10.53$ & $\begin{array}{l}\text { Unpaired t test: } \mathrm{t}=14.38 ; \mathrm{p}<0.0001 ; \\
\text { Highly significant }\end{array}$ \\
\hline
\end{tabular}

As shown in Table 5, the rise in mean haemoglobin level at 4 weeks was also more in Group A as compared to Group B (1.79 vs $1.06 \mathrm{gm} / \mathrm{dl})$. Statistically, the rise was highly significant $(\mathrm{p}<0.0001)$.

Table 6 shows the rise in mean serum ferritin level at 4 weeks which was also more in Group A as compared to Group B (123.80 vs $84.78 \mathrm{mcg} / \mathrm{L})$. Statistically, the rise was also highly significant $(\mathrm{p}<0.0001)$.

Table 7 shows the adverse effects noted in the two groups. Only mild side effects were noted after administration of the drugs. None of the patients presented with more than one side effect.

In Group A, $12 \%$ patients had skin discoloration, while $6 \%$ each had headache and constipation. $4 \%$ had diarrhoea and $2 \%$ each had nausea, injection site reactions and vomiting. In Group B $12 \%$ patients complained of diarrhoea, $8 \%$ each had constipation and injection site reactions, $6 \%$ had vomiting, $6 \%$ each had nausea, constipation, abdominal pain and injection site reactions. $4 \%$ each had abdominal pain, headache, dysgeusia and skin discoloration.
Table 7: Adverse drug reactions.

\begin{tabular}{|c|c|c|c|}
\hline $\begin{array}{l}\text { Adverse drug } \\
\text { reactions }\end{array}$ & $\begin{array}{l}\text { Group A } \\
\text { No. }(\%)\end{array}$ & $\begin{array}{l}\text { Group B } \\
\text { No. }(\%)\end{array}$ & $\begin{array}{l}\text { Statistical } \\
\text { inference }\end{array}$ \\
\hline Diarrhea & $2(4.00)$ & $6(12.00)$ & \multirow{14}{*}{$\begin{array}{l}\text { Chi-square } \\
\text { value }=3.30 \\
48 ; \\
p=0.69 ; \\
\text { Not } \\
\text { significant }\end{array}$} \\
\hline Nausea & $1(2.00)$ & $1(2.00)$ & \\
\hline Constipation & $3(6.00)$ & $4(8.00)$ & \\
\hline $\begin{array}{l}\text { Abdominal } \\
\text { pain }\end{array}$ & $0(0.00)$ & $2(4.00)$ & \\
\hline $\begin{array}{l}\text { Injection site } \\
\text { reactions } \\
\text { (pain, swelling, } \\
\text { burning, } \\
\text { irritation) }\end{array}$ & $1(2.00)$ & $4(8.00)$ & \\
\hline Headache & $3(6.00)$ & $2(4.00)$ & \\
\hline Dysgeusia & $0(0.00)$ & $2(4.00)$ & \\
\hline $\begin{array}{l}\text { Skin } \\
\text { discoloration }\end{array}$ & $6(12.00)$ & $2(4.00)$ & \\
\hline Vomiting & $1(2.00)$ & $3(6.00)$ & \\
\hline $\begin{array}{l}\text { Hypersensitive } \\
\text { reaction }\end{array}$ & $0(0.00)$ & $0(0.00)$ & \\
\hline Hypertension & $0(0.00)$ & $0(0.00)$ & \\
\hline Hot flushing & $0(0.00)$ & $0(0.00)$ & \\
\hline Hypotension & $0(0.00)$ & $0(0.00)$ & \\
\hline Total & $17(34.00)$ & $26(52.00)$ & \\
\hline
\end{tabular}


In Group A, adverse reactions were observed in $34 \%$ patients, while in Group B it was observed in 52\% patients. However, the difference in number of episodes in the two groups was statistically not significant $(p=0.69)$. No anaphylactic reactions or any other serious side effects were noted after the infusions in either group.

Table 8: Comparison of two groups according to the results obtained.

\begin{tabular}{|l|l|l|}
\hline $\begin{array}{l}\text { Variable (Mean } \pm \text { SD) } \\
\text { Baseline hemoglobin } \\
\text { (gm\%) }\end{array}$ & $8.45 \pm 0.64$ & $8.40 \pm 0.64$ \\
\hline $\begin{array}{l}\text { Hemoglobin }(\mathrm{gm} / \mathrm{dl}) \\
\text { rise at 4 weeks }\end{array}$ & $1.79 \pm 0.47$ & $1.06 \pm 0.11$ \\
\hline $\begin{array}{l}\text { Baseline serum ferritin } \\
\text { (mcg/l) }\end{array}$ & $14.09 \pm 6.05$ & $14.74 \pm 5.82$ \\
\hline $\begin{array}{l}\text { Serum ferritin (mcg/l) } \\
\text { rise at 4 weeks }\end{array}$ & $123.80 \pm 16.03$ & $84.78 \pm 10.53$ \\
\hline $\begin{array}{l}\text { Adverse drug reactions } \\
(\%)\end{array}$ & 34 & 52 \\
\hline
\end{tabular}

Table 8 sums up the comparison between the two groups. As is shown in the table, iron carboxy-maltose group leads to a higher rise in the haemoglobin and serum ferritin levels and lower incidence of adverse drug reactions as compared to the iron sucrose group.

\section{DISCUSSION}

In the present study, the mean age of Group A was $26.46 \pm 3.58$ years and mean age of group B was $24.64 \pm 2.87$ years, which was comparable $(p=0.006)$ (Table 1). Metgud MC et al, conducted a study in the Gynae department of a hospital in Karnataka, India where the mean age was $25.33 \pm 3.53$ in FCM group vs $24.85 \pm 4.18$ years in Iron Sucrose group. ${ }^{8}$ Joshi SD et al, conducted a similar prospective study on 100 antenatal patients in VIMS, Karnataka with the mean age group in the FCM group 22.56 years and 25.1 years in Iron Sucrose group, with the majority of patients belonging to the age group of 21-25 years of age. ${ }^{9}$ The age group of 20-29 years is found to be more prone to anaemia probably because of increased demand, improper dietary habits, lack of health education and iron deficiency during the adolescence period. $44 \%$ of patients in Group A and $38 \%$ in Group B were primigravidae, while $56 \%$ of patients in Group A and 62\% in Group B were multigravida. In the study conducted by Metgud MC et al, $56.86 \%$ of females were multigravida in FCM group and $76.9 \%$ in the iron sucrose group. ${ }^{8}$ Higher incidence of anaemia in multigravida is because multiple pregnancies especially without proper spacing leads to consumption of iron stores without adequate time for replenishment.

Mean values of hemoglobin pre-infusion in Group A was $8.45 \pm 0.64 \mathrm{gm} / \mathrm{dl}$ and in Group B $8.40 \pm 0.64 \mathrm{gm} / \mathrm{dl}$, the difference being statistically insignificant $(\mathrm{p}=0.69)$ (Table 3 ). This is consistent with the study conducted by Metgud $\mathrm{MC}$ et al, where the pretreatment mean $\mathrm{Hb}$ was $8.70 \pm 0.84$ $\mathrm{gm} / \mathrm{dL}$ in FCM group while in IS group it was $8.82 \pm 0.84$ $\mathrm{gm} / \mathrm{dL} .{ }^{8}$ Mean serum ferritin of Group A was $14.09 \pm 6.05$ $\mathrm{mcg} / \mathrm{L}$ and that of Group B was $14.74 \pm 5.82 \mathrm{mcg} / \mathrm{L}$, the difference being statistically insignificant $(\mathrm{p}=0.58)$ (Table 4).

The rise in mean hemoglobin at 4 weeks in Group A was $1.79 \pm 0.47$ and $1.06 \pm 0.11$ in Group B which was highly significant (p-value <0.0001) (Table 5). These results were consistent with the study of Garg R et al, who found the mean increase in $\mathrm{Hb}$ after 4 weeks to be $2.48 \mathrm{gm} / \mathrm{dL}$ in FCM group and $2.10 \mathrm{gm} / \mathrm{dL}$ in IS group. ${ }^{10}$ Similarly, Metgud MC et al, also reported higher rise in $\mathrm{Hb}$ in the patients receiving FCM $(2.27 \mathrm{gm} / \mathrm{dL})$ versus $\mathrm{Hb}$ in the patients receiving IS infusion $(2.17 \mathrm{gm} / \mathrm{dL}){ }^{8}$ Joshi SD et al, also found the mean increase in $\mathrm{Hb}$ after 4 weeks of treatment to be 2.09 in the FCM group and 1.82 in the IS group and Maheshwari B et al, found it to be $3.59 \mathrm{gm} / \mathrm{dL}$ in the patients receiving $\mathrm{FCM}$ vs $2.34 \mathrm{gm} / \mathrm{dL}$ in the patients receiving IS infusion. ${ }^{9,11}$

Rise in mean serum ferritin level at 4 weeks in Group A was $123.80 \pm 16.03$ and in Group B was $84.78 \pm 10.53$. Statistically, the rise was also highly significant $(\mathrm{p}<0.0001)$ (Table 6). Boughton $\mathrm{S}$ et al, found the post transfusion rise of S. ferritin in their study to be 296 $\mathrm{mcg} / \mathrm{L}$ in FCM group whereas it was only $105 \mathrm{mcg} / \mathrm{L}$ in the IS group after 4 weeks of treatment. Maheshwari B et al, found the rise in S. ferritin after 4 weeks to be only $22.54 \mathrm{mcg} / \mathrm{L}$ in case of FCM and $5.05 \mathrm{mcg} / \mathrm{L}$ in case of IS infusion i.e. more in case of FCM infusion. ${ }^{11-13}$ Patel $\mathbf{J}$ et al, found the rise to be $9.4 \mathrm{mcg} / \mathrm{L}$ for patients transfused with FCM and $9.1 \mathrm{mcg} / \mathrm{L}$ for those who got IS after 2 weeks of treatment. Serum Ferritin is the measure of iron stores the body. ${ }^{13}$ In present study authors found its rise to be more in case of FCM infusion.

In present study, adverse reactions were observed in $34 \%$ patients in Group A, while in Group B it was observed in $52 \%$ patients. Group A, $12 \%$ patients had skin discoloration, while $6 \%$ each had head-ache and constipation. $4 \%$ had diarrhea and $2 \%$ each had nausea, injection site reactions and vomiting. In Group B 12\% patients complained of diarrhea, $8 \%$ each had constipation and injection site reactions, $6 \%$ had vomiting, $6 \%$ each had nausea, constipation, abdominal pain and injection site reactions. $4 \%$ each had abdominal pain, headache, dysgeusia and skin discoloration. Garg $\mathrm{R}$ et al, in their study found adverse effects in $16 \%$ of patients in FCM group and $20 \%$ of patients in IS group, the most common being pain at injection site $(8 \%)$ in IS group and transient hypotension (4\%) in FCM group, while Maheshwari B et al found the same in $28.96 \%$ of patients receiving FCM and $31.58 \%$ of patients receiving IS. ${ }^{10,11}$ Boughton $\mathrm{S}$ et al, in their study found adverse effects in $16 \%$ of patients in FCM group and $34 \%$ of patients in IS group while Joshi SD et al found $14 \%$ adverse drug reactions in FCM group and $20 \%$ in IS group. ${ }^{9,12}$ Hence, the incidence of side effects was less with FCM as compared to iron sucrose group. 
Table 8 shows a comparison of both the drugs in terms of baseline parameters i.e. mean hemoglobin levels and mean serum ferritin taken before infusion and how they were affected post infusion of ferric carboxy maltose and Iron Sucrose along with the percentage of the adverse effects noted.

\section{CONCLUSION}

Ferricarboxymaltose has shown to increase haemoglobin and serum ferritin levels significantly more than Iron Sucrose and has lesser incidence of adverse drug reactions making it a better choice for the treatment of iron deficiency anaemia in pregnant women.

Funding: No funding sources

Conflict of interest: None declared

Ethical approval: The study was approved by the Institutional Ethics Committee

\section{REFERENCES}

1. Kumar KJ, Asha N, Murthy DS, Sujatha MS, Manjunath VG. Maternal anemia in various trimesters and its effect on newborn weight and maturity: an observational study. Int J Prev Med. 2013;4(2):193.

2. Marahtta R. Study of anaemia in pregnancy and its outcome in Nepal Medical College teaching Hospital, Kathmandu, Nepal. Nepal Med Coll J. 2007;9(4):270-4.

3. Rani KU, Gupta J, Gupta R, Aggarwal KC. Maternal anaemia and its severity: an independent risk factor for preterm delivery and adverse neonatal outcome. Int J Reprod Contracept Obstet Gynecol. 2014;3(2):325-9.

4. Batar A, Salvi A, Saini L, Agarwal S, Rajoria L, Mital P. Maternal and perinatal outcome of pregnancy with severe anaemia. Int $\mathrm{J}$ Biomed Adv Res. 2015;6(08):611-6.

5. Auerbach M, Adamson J. How we diagnose and treat iron deficiency anaemia. Am J Hematol. 2016;9(1):31-9.
6. Gautham KSK. Intravenous iron sucrose. World J Anaemia. 2017;(1):20-2.

7. Lyseng-Williamson KA, Keating GM. Ferric carboxymaltose: a review of its use in irondeficiency anaemia. Drugs 2009; 69(6):739-56.

8. Metgud MC, Metgud SB, Bellad MB, Metgud SH. Comparison of efficacy and safety of intravenous ferric carboxymaltose vs iron sucrose in the treatment of antepartum iron deficiency anaemia: a randomized controlled trial. J South Asian Feder Obst Gynae. 2016;8(4):314-8.

9. Joshi SD, Chikkagowdra S, Kumar V. Comparative study of efficacy and safety of intravenous ferric carboxymaltose versus iron sucrose in treatment of postpartum iron deficiency anaemia. Int J Reprod Contracept Obstet Gynecol. 2016;5(8):2566-70.

10. Garg R, Nigam A, Agrawal P, Nigam A, Agrawal R. Iron Carboxymaltose: A Safe and Effective Molecule to Combat Anaemia in Pregnancy. Int J Curr Res Aca Rev 2016;4(2):124-30.

11. Maheshwari B, Mahtab V, Tyagi S, Tyagi P. Evaluation of efficacy, safety and cost effectiveness of oral iron and injectable iron sucrose and ferric carboxy maltose in pregnant women in 2nd and 3rd trimester in anaemia. Ind $\mathbf{J}$ Obstet Gynecol Res. 2017;4(1):96-100.

12. Boughton S, Chen L, Kidson-Gerber G, Curtain C, Zaidi ST, Henry A. Intravenous iron sucrose and ferric carboxymaltose in pregnant patients: an observational study of maternal efficacy and tolerance. J Pharmacy Pract Res. 2017;47(6):419-25.

13. Patel J, Patel K, Sharma A, Date SK. Comparison of intravenous Iron sucrose and intravenous Ferric carboxymaltose therapy in iron deficiency anemia during pregnancy and postpartum period. J Pharmac Sci Bioscient Res. 2015;5(3):239-43.

Cite this article as: Sunil I, Kour P, Sharma M. Comparison of iron carboxy maltose and iron sucrose in pregnant females. Int J Reprod Contracept Obstet Gynecol 2019;8:697-701. 